A. Szeinberg, Ph. D., Ch. Sheba, M. D., A. Adam, M. Sc. and Bracha Ramot, M. D.

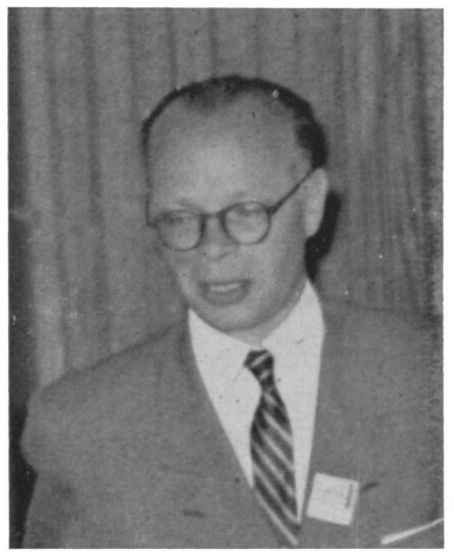

\title{
A hereditary abnormality of the metabolism of glutathione in the red blood cells*
}

The hereditary abnormality of erythrocytes first described by Beutler and assoc. in primaquine sensitive American Negroes, has also been detected in oriental Jews sensitive to hemolysis by sulphonamides, fava beans and possibly other agents.

The frequency of this erythrocyte abnormality among various communities in Israel was investigated by the glutathione stability test in a random sampled population. Individuals, whose erythrocyte glutathione (GSH) fell below $30 \mathrm{mg} / \mathrm{IoO} \mathrm{cc}$ $\mathrm{RBC}$ as a result of incubation with acetylphenylhydrazine were considered as abnormal.

Among 400 random sampled Ashkenazic Jews from eastern, central or western Europe this defect was not detected. However the abnormality is evidently not completely absent among this population group. Recently a case of favism in an adult Ashkenazic Jew born in Poland came to our attention. The patient's erythrocytes demonstrated glutathione instability and a severe deficiency of glucose 6 phosphate dehydrogenase.

On the other hand glutathione instability was found frequently in the erythrocytes of oriental Jews (Table I). The highest frequency of the abnormality (above $30 \%$ ) was encounterd among Jews from Kurdistan, followed by those from Iraq and Persia. The geographic proximity of those places could suggest a common source for this high frequency. Frequency of about $8 \%$ was found among the Turkish Jews, but it is not certain yet whether some of them did not originate from Kurdistan or Iraq (taking into consideration the proximity of these regions and the tendency to

* This investigation has been supported by the Rockefeller Foundation. 
Table I - GSH stability test in various Jewish groups in Israel

\begin{tabular}{|c|c|c|c|c|}
\hline \multirow{2}{*}{ Origin of subjects } & \multicolumn{2}{|c|}{ Males } & \multicolumn{2}{|c|}{ Females } \\
\hline & No. examined & $\%$ sensitive $^{1}$ & No. examined & $\%$ sensitive $^{1}$ \\
\hline$\therefore$ Iraq & 246 & $25.2 \%$ & 278 & $31.4 \%$ \\
\hline Kurdistan & $4^{6}$ & $36.5 \%$ & 70 & $37.5 \%$ \\
\hline Persia & 106 & $19.5 \%$ & 137 & $20.7 \%$ \\
\hline Turkey & 79 & $7.6 \%$ & $\log$ & $7.4 \%$ \\
\hline Cochin & 49 & $12.0 \%$ & 34 & II. $7 \%$ \\
\hline Yemen & $15 \mathrm{I}$ & $6.0 \%$ & 195 & $6.1 \%$ \\
\hline North Africa & 170 & $\mathrm{I} .8 \%$ & 250 & $1.2 \%$ \\
\hline
\end{tabular}

Subjects with glutathione instability have been detected also among Jews from Egypt, Sudan, Aden, Syria, Caucasus, Buchara, and Italy.

Table 2 - GSH stability test in various national and religious groups in Israel

\begin{tabular}{|c|c|c|c|c|}
\hline \multirow{2}{*}{ Subjects } & \multicolumn{2}{|c|}{ Males } & \multicolumn{2}{|c|}{ Females } \\
\hline & No. examined & sensitive ${ }^{2}$ & No. examined & sensitive ${ }^{2}$ \\
\hline Karaites & 26 & o & 15 & o \\
\hline Samaritans & 6 & o & & \\
\hline Arabs & 120 & $3 \cdot 3 \%$ & 89 & $3.4 \%$ \\
\hline Druses & 90 & $5.5 \%$ & 10 & o \\
\hline Desert Bedouins & 12 & I case & 17 & I case \\
\hline Circasians & 40 & o & & \\
\hline Sikh (Punjab) & I & I case & & \\
\hline
\end{tabular}

migration). Subjects from Cochin at the south western tip of the Indian peninsula showed a frequency of about $12 \%$, while the Yemenites about $6 \%$. The abnormality is evidently not common among the North African Jews. Other Jewish communities have not yet been studied in sufficient numbers to allow conclusions about the relative frequency, but the abnormality has also been detected among Jewish subjects from Egypt, Sudan, Aden, Caucasus, Buchara and Italy.

The abnormality has also been detected among Arabs, desert Bedouins and Druses living in Israel. It is of interest that the single Sikh from Punjab examined by us while in transit in Israel demonstrated also this erythrocyte abnormality (table 2).

\section{The pattern of genetic transmission}

In a paper recently published we proposed a hypothesis that the abnormality in our community is inherited through a sex linked gene with incomplete dominance. We may now add some additional evidences of the sex linkage to the chromosome $\mathrm{X}$.

1 Subjects, whose erythrocyte GSH fell below 30mg/1oo cc RBC during incubation with acetylphenylhydrazine.

2 Subjects whose erythrocyte GSH fell below $30 \mathrm{mg} / \mathrm{I} 00$ cc RBC during incubation with acetylphenylhydrazine. 
In table 3 we present families which came to our attention through affected children. The number of families in which the abnormality was transmitted through the mother was much higher than the number of families in which the father was the only source of the pathologic gene. This finding is in accord with the sex linkage hypothesis. If we assume that in the families in which both parents were normal, the mother was a carrier of the pathologic gene without penetrance (the validity of such an assumption was discussed by us in a previous communication), the preponderance of cases with transmittance through the mother is still more striking.

Table 3 - GSH instability in parents in families detected trough children (in all cases both parents were examined)

\begin{tabular}{lc}
\hline GSH instability & No. of families \\
Only in father & 8 \\
Only in mother & 18 \\
In both parents & 7 \\
\hline No GSH instability in parents & 7 \\
\hline Total families & 40
\end{tabular}

Table 4 - Findings in the offsprings in families, in which the father exhibited GSH instability and the mother was normal

\begin{tabular}{lc}
\hline \hline Findings in children & No. of families \\
All daughters , sensitive" & I \\
All daughters ,, sensitive" and all & 7 \\
$\quad$ sons normal & 3 \\
All sons normal & I \\
\hline Some daughters normal & 2 \\
All sons and daughters normal & I \\
Some of sons,, sensitive" & I5 \\
Total families & \\
"Sensitive"-subjects with GSH instability.
\end{tabular}

In 15 families studied by us the father showed erythrocyte GSH instability while the mother was normal. When a certain condition is transmitted as a dominant trait with complete sex linkage to the chromosome $\mathrm{X}$, all the daughters in families of the type presented in table 4 should show the abnormality, while all the sons should be normal. In I I out of our I 5 families this condition was fullfilled. The seemingly contradicting findings in the remaining 4 families might be explained by the non penetrance of the gene in some females. An alternative hypothesis for the last family in this table, in which the abnormality was found in the father and some of his sons, could be, that the gene is situated on the homologous segment of the X chromosome, so that crossovers are possible. 


\section{Expressivity of the gene in females}

Childs and assoc. studying the glutathione instability in American Negroes postulated that all the females with glutathione levels below 2omg/roocc RBC (after incubation with acetylphenylhydrazine) should be considered as homozygous for the abnormal gene. However one family in their material did not conform to this postulation.

In figure I we present some families from our material incostistent with the hypothesis that all females with the low GSH levels homozygous. In the families I, 2, 3
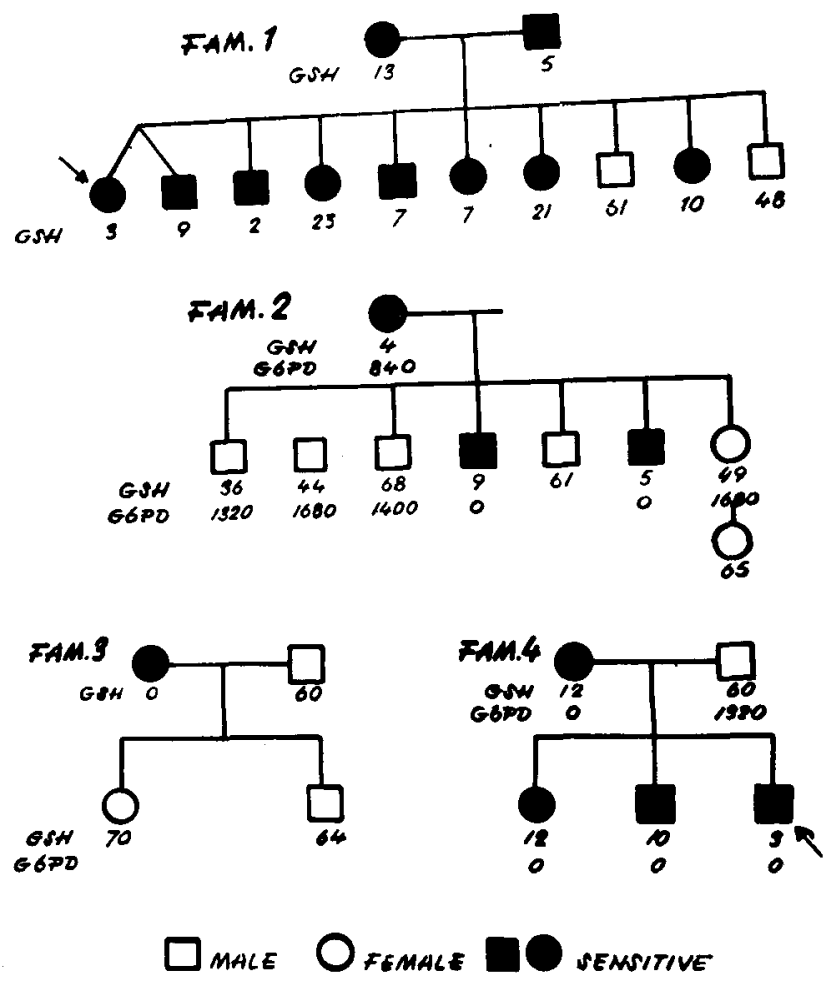

Families incompatible with the hypothesis that all females with GSH level of o-20 mg/roo cc RBC after incubation with acetylphenylhydrazine are homozygous.

the mothers must be heterozygous, since some of their sons were normal. In family 4 the daughter must be heterozygous as here father had normal GSH stability. These families suggest that a full expressivity of the defect might be found also in heterozygous females.

Evidence in the same direction is afforded by mathematical considerations; When the frequency of the pathologic gene was calculated for 4 different communities 
(Jews from Kurdistan, Iraq, Persia and Yemen) by the " maximal likelihood method" advocated by Neel and Shull, on the assumption that all the females with GSH values o-20 mg/roo cc RBC (after incubation with acetylphenylhydrazine) are homozygous, a great divergence between the expected and the observed values has been seen both for males and females. It suggested, that either the hypothesis of transmission by a sex linked incompletely dominant gene is incorrect, or that some females with the low GSH values are heterozygous.

Table 5 - Correlation between the degree of GSH stability and glucose 6 phospate dehydrogenase activity in males and females

\begin{tabular}{|c|c|c|c|c|c|}
\hline \multirow{2}{*}{ GSH $^{3}$} & \multicolumn{5}{|c|}{ Glucose 6 phosphate dehydrogenase activity 4} \\
\hline & Total examined & 0 & $200-800$ & $800-1000$ & $1000-2500$ \\
\hline & \multicolumn{5}{|c|}{ Number of males } \\
\hline $0-10$ & 36 & $3^{6}$ & & & \\
\hline $1 \mathrm{I}-2 \mathrm{O}$ & 4 & 4 & & & \\
\hline $3^{I-40}$ & 2 & & & & 2 \\
\hline \multirow[t]{2}{*}{ above $4^{\circ}$} & $5^{I}$ & & & & $5^{1}$ \\
\hline & \multicolumn{5}{|c|}{ Number of females } \\
\hline o-10 & $2 I$ & 14 & 7 & o & o \\
\hline II -20 & 14 & 3 & 9 & 2 & 0 \\
\hline $21-30$ & 15 & 0 & 4 & 7 & 4 \\
\hline $3 \mathbf{I}-40$ & $\mathrm{I} 2$ & & & & 12 \\
\hline above 40 & $4^{6}$ & & & & $4^{6}$ \\
\hline
\end{tabular}

Additional proof that the females with these low GSH values do not constitute a homogenous group is presented by the investigation of the glucose 6 phosphate dehydrogenase activity. It is shown in table 5 that no activity of this enzyme was demonstrated by our method ${ }^{5}$ in any of the males with the GSH instability, while only a part of the females with the low GSH values have shown a similar absence of the enzyme activity. In a considerable proportion of females belonging to this GSH group intermediate levels of activity of this enzyme were demonstrated. On the basis of these findings, it would be possible to suppose that by the estimation of the glucose 6 phosphate dehydrogenase activity it would be possible to differentiate with certainty between the homo-and heterozygous females. But in our material we have already one family inconsistent with such a supposition. In the family No. 4 in fi-

${ }^{3} \mathrm{GSH} \mathrm{mg} / \mathrm{100}$ cc RBC after incubation with acetyphenylhydrazine.

4 Glucose 6 phosphate dehydrogenase activity in units/Icc RBC/min.

5 The activity of the glucose 6 phosphate dehydrogenase was estimated by the increase of optical density at $340 \mathrm{mM}$ of a mixture which contained tris buffer, hemolyzate incubated previously for 60 minutes at $37^{\circ}$, glucose 6 phosphate, triphosphopyridine nucleotide and $\mathbf{M g C l}_{2}$. 
gure I the daughter with no demonstrable activity of this enzyme should be considered heterozygous because of her normal father (unless he is not her real father).

The consideration of our material suggests, that in the heterozygous females a complete range of variability of expressivity of the defect may be encountered, from full dominance to non penetrance.

It is possible to postulate, that perhaps some additional factor, unknown to us yet is conditioning the degree of expressivity in females.

\section{Summary}

The frequency of a hereditary abnormality of erythocytes characterised by a deficiency in glucose 6 phosphate dehydrogenase and glutathione instability, has been investigated in various population groups in Israel. The highest frequencies of this abnormality have been detected among Jews from Kurdistan, Iraq and Persia. It is also relatively common in other oriental (sefardic) Jewish communities, as well as among Arabs, desert Bedouins and Druses.

Up to now only one case of this erythrocyte defect has been found among Jews of Ashkenazic origin. The same abnormality has also been found in a Sikh from Punjab.

The hereditary pattern of transmission and evidences of sex linkage are presented. The problem of expressivity of the abnormal gene in heterozygous females is discussed.

\section{RIASSUNTO}

Ricerche sono state effettuate in vari gruppi etnici in Israele sulla frequenza di un difetto creditario degli eritrociti, caratterizzato da deficienza in glucosio-6-fosfato deidrogenasi e da un'istabilità del glutatione stesso.

$\mathrm{La}$ più alta frequenza di questa anomalia è presente negli Ebrei provenienti dal Kurdistan, dall'Iraq e dalla Persia. È pure relativamente comune tra le altre comunità ebraiche orientali (sefarditi), come pure tra Arabi, Beduini e Drusi.

Per conoscenza, soltanto un caso di questo difetto eritrocitario è stato trovato tra Ebrei di origine non orientale (Askenaziti). La stessa anormalità era presente pure in un Sikh del Punjab.

Si presentano in questo lavoro lo schema genetico di trasmissione e l'evidenza di un " sexlinkage ». Si discute pure il prob!ema dell'espressività del gene anormale in individui di sesso femminile eterozigoti.
RÉSUMÉ

La fréquence d'une anomalie héréditaire des érythrocytes, caractérisée par une déficience en glucose 6-phosphate déhydrogenase et en une instabilité du glutathion a été etudiée dans les divers groupes ethniques en Israel. $\mathrm{La}$ fréquence la plus élevée de cette anomalie a été constatée parmi les Juifs originaires du Kurdistan, de l'Iraq et de Perse. Elle est aussi relativement fréquente parmi les Juifs provenants d'autres communautés orientales (Séphardiques) et également parmi les Arabes, les Bedouins du desert et les Druses.

Jusqu'à présent un seul cas de cette anomalie érythrocytaire a été trouvé chez un juif d'origine Ashkénaze. La même anomalie a été trouvée chez un Sikh de Punjab.

La mode de transmission héréditaire et l'évidence de liaison au sexe sont présentés.

Sonit discutés également les problèmes de l'expressivité du gène anormal dans les femelles hétérozygotes. 


\section{ZUSAMMENFASSUNG}

Die Haeufigkeit einer erblichen Anomalie der roten Blutkoerperchen, bestehend in einem Mangel an Glucose-6-Phosphate-Dehydrogenase und einer fehlenden Stabilitaet des Glutathions, wurde in verschiedenen Bevoelkerungsgruppen in Israel untersucht. Die groesste Haeufigkeit dieser Anomalie wurde unter Juden aus Kurdistan, Iraq und Persien angetroffen. Die Anomalie ist auch relative haeufig unter anderen orientalischen (Sefardischen) Juden, als auch unter Arabern, Wuesten-Beduinen und Drusen.

Bis her wurde nur ein einziger Fall dieses Ery trocytendefects unter Juden Ashkenazischen Ursprunges vorgefunden. Die gleiche Anomalie wur de auch in einem Sikh aus Punjab beobachtet.

Die Vererbungsgesetze und der Nachweis einer Geschlechtsbedingung dieser Anomalie wurden beschrieben. Die Frage der Erscheinungsform des abnormalen Genes in heterozygoten Frauen wird diskutiert. 